\title{
Interesting Mosses from Elbow Forest Preserve in Southern Saskatchewan
}

\author{
by Bernard de Vries, University of Manitoba, Winnipeg.
}

In the summer of 1960 the writer discovered four interesting species of moss in the Elbow Forest Preserve in southern Saskatchewan. They were identified by Dr. H. Crum of the National Museum of Canada, and verified by Dr. C. D. Bird of the University of Alberta, Calgary, Alberta. The species in question were:

Cratoneuron filicinum (Hedw.) Spruc., de Vries \#897, collected on a damp grassy hummock in wet meadow at the base of Salix brebbiand, in association with Philonotis fontana.

Drepanocladus vernicosus (Lindb.) Warnst., de Vries \#915, collected on a damp grassy hummock in a wet meadow.

Meesia triquetra (Hook \& Tayl.) Aongstr., de Vries \#914, collected on a damp grassy hummock in a wet meadow at the base of Salix bebbiana var. perrostrata.

Philonotis fontana (Hedw.) Brid., de Vries \#913, collected on a damp grassy hummock in a wet meadow at the base of Salix bebbiana, in association with Cratoneuron filicinum.

These collections are of interest for they shed new light on the moss flora of Saskatchewan and indicate how little we know of mosses in Saskatchewan. The collections of Drepanocladus vernicosus and Philonotis fontana are the first reports of these species for Saskatchewan. Bird (1962. Catalogue of the Bryophytes reported from Alberta, Saskatchewan, and Manitoba. Litho. Botany Dept., Univ. Alberta, Edmonton) recorded these two plants from neighbouring Alberta and Manitoba so my collections indicate that they may be found to be not uncommon in Saskatchewan in similar habitats.

My collection \#897, Cratoneuron filicinum, is the first collection for Saskatchewan with exact location since Macoun's early collection from Medicine Lodge south of Wood Mountain. This plant is probably not uncommon and may be found in springy places throughout southern Saskatchewan.

Meesia triquetra ( $M$. Tristicha) has been reported frequently from Alberta and Manitoba but it has not been collected in Saskatchewan since Thomas Drummond collected it along the Saskatchewan River near Cumberland House early in the last century. Voucher specimens with the writer's collection numbers are deposited in the National Museum of Canada, Ottawa, and the University of Alberta, Calgary, as well as in my own private herbarium.

The area in which this meadow occurs contains undifferentiated sands with a level to undulating topography. The meadow is located some four miles northeast of Aikow siding and about twelve miles southeast of Elbow. Aikow Creek, which is a part of the Qu'Appelle River system, runs roughly west of the area. The Elbow Forest Preserve is a part of the aspen parkland that extends southwards from the main zone along the South Saskatchewan River.

The meadow, in which the above mosses were fairly abundant, was surrounded by aspen and willows. The meadow had been subjected to grazing pressure and an active beaver colony was a disrupting factor in the community. Plants with which the mosses were associated are as follows: Carex rostrata Stokes, Salix bebbiana Sarg., S. bebbiana var. perrostrata Schneid., Salix candida Fluegge, Salix serissima (Bailey) Fern., Betula glandulosa Michx., B. glandulosa var. glanulifera (Regel) Gl., Parnassia palustris L., Gentiana crinita Froel., Veronica americana (Raf.) Schwein., Lobelia kalmia L., Bidens cernua L. Lack of time prevented examination of similar meadows in the area.

Special thanks are extended to Dr. B. Boivin, Canada Department of Agriculture Research Station, Ottawa, for checking the-identifications of associated flora and to Dr. C. $D$. Bird who read the manuscript and offered helpful suggestions. 